\title{
Aboriginal forestry entrepreneurship: A case study in Mashteuiatsh Ilnu Nation
}

\author{
by Jean-Michel Beaudoin1,2, Luc LeBel1,3 and Luc Bouthillier1,4
}

\begin{abstract}
The participation of the First Nations in Canadian forestry is a growing and irreversible phenomenon. There is a lack of information on forestry initiatives in Aboriginal communities, particularly regarding factors contributing to entrepreneurial development within Aboriginal communities. It is in this context that we present a case study that allowed us to draw a portrait of forestry entrepreneurs within the Ilnu community of Mashteuiatsh. Our results reveal the determinant but delicate role played by the band council in developing forestry entrepreneurship in the community. Our research also indicates that it is essential to define the roles of various economic and political stakeholders in order to promote private forestry initiatives.
\end{abstract}

Key words: Aboriginal people, forestry, economic development, entrepreneurship

\section{RÉSUMÉ}

La participation des Premières Nations à la foresterie canadienne est un phénomène en croissance et irréversible. Il existe un manque d'information sur les initiatives forestières des communautés autochtones. En particulier, les facteurs contribuant au développement entrepreneurial au sein des communautés autochtones sont méconnus. Avec létude du cas de la communauté Ilnu de Mashteuiatsh, nous présentons un portrait des entrepreneurs forestiers autochtones. Nos résultats révèlent le rôle déterminant mais délicat joué par le conseil de bande pour développer l’entrepreneuriat forestier dans la communauté. Notre recherche montre aussi qu’il est essentiel de préciser les rôles des différents acteurs économiques et politiques afin de favoriser les initiatives privées en foresterie.

Mots-clés : peuples autochtones, foresterie, développement économique, entrepreneuriat

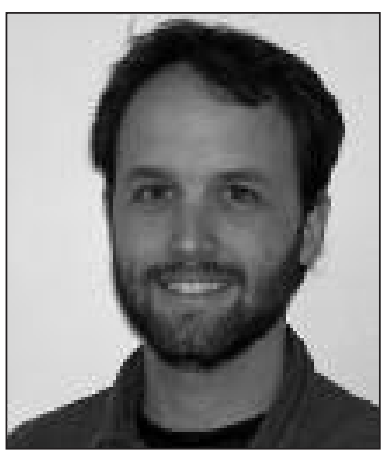

Jean-Michel Beaudoin

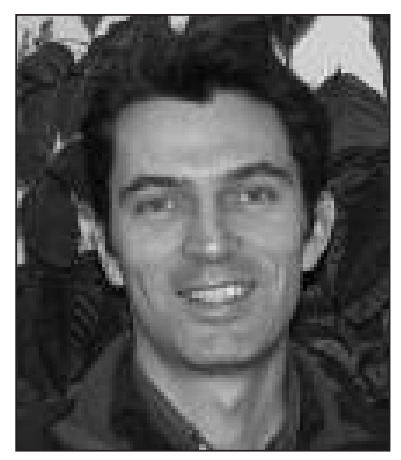

Luc LeBel

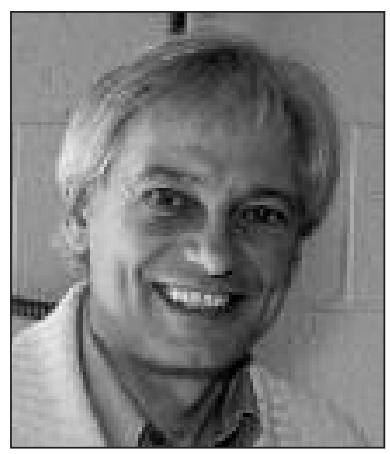

Luc Bouthillier

Anderson and Giberson 2004, Wyatt 2008). Since 1996, the First Nations Forestry Pro$\operatorname{gram}^{5}$ (FNFP) has encouraged Aboriginal communities to play an increased role in the development of forest resources (FNFP 2008). This is a major issue in all Canadian provinces, which are all home to Aboriginal communities interested in taking part in forestry (Hutton 2004, FNFP 2008, Trosper et al. 2008, Wyatt 2008). Unfortunately, our research reveals a lack of

\section{Introduction}

In Canada, $80 \%$ of Aboriginal communities are located in commercial forestry zones (Curran and M'Gonigle 1999). In recent decades, many communities have developed their abilities in the forestry sector in order to increase their level of autonomy, strengthen their traditional values, and self-sufficiency and to improve living conditions (NAFA-IOG 2000, information on Aboriginal business initiatives in forestry. A report commissioned by the FNFP recommends "improving the gathering of data on relations between the First Nations and the forestry sector and carrying out research on lessons

${ }^{5}$ http://cfs.nrcan.gc.ca/subsite/fnfp

\footnotetext{
${ }^{1}$ Département des sciences du bois et de la forêt, Faculté de foresterie et de géomatique, Pavillon Abitibi-Price, 2405 rue de la Terrasse, Université Laval, Québec (Québec) G1V 0A6.

${ }^{2}$ Graduate research assistant. E-mail: jean-michel.beaudoin.1@ulaval.ca

${ }^{3}$ Professor. E-mail: Luc.Lebel@sbf.ulaval.ca

${ }^{4}$ Professor. E-mail: Luc.Bouthillier@sbf.ulaval.ca
} 
learned from business partnerships" (Graham and Wilson 2004, p. 40). Many questions on Aboriginal forestry initiatives have yet to be addressed.

To begin, the nature of Aboriginal forestry should be examined. Wyatt (2008), for example, suggests a conceptual framework on Aboriginal participation in Canadian forestry. This framework identifies 4 different variants. The first is "forestry by the First Nations" which simply means involving First Nations in the conventional forestry model. The second is "forestry for the First Nations," where conventional forest management takes into account First Nations values, needs, and knowledge. He also identifies "forestry with the First Nations," or forestry in which First Nations are full partners in forest management. Finally, Wyatt describes what could be called "First Nations forestry," which, according to this author, we have yet to see. This would be a situation where traditional culture and knowledge are combined with conventional forestry in order to instil forestry practices that would be specific to First Nations occupation of a forest.

Wyatt's (2008) paper leads us to a second question, namely "How would Aboriginal forestry be different from conventional forestry?" Some interesting points were raised regarding indigenous entrepreneurship. According to Hindle and Lansdowne (2005), it is not sufficient to have a degree of indigenous ownership to talk about indigenous entrepreneurship. Heritage and culture must be a central issue. Lindsay et al. (2007) demonstrate that indigenous entrepreneurs are highly empathetic, which they define as having a disposition to identify with one's heritage, territory, family, community, and culture. Many authors mention the community orientation of indigenous entrepreneurship (Hindle and Lansdowne 2005; Lindsay et al. 2006, 2007; Peredo and Anderson 2006).

One final question seems equally fundamental: Which specific factors contribute to the success or failure of Aboriginal forestry initiatives? Recent research by Trosper et al. (2008, p. 226) has demonstrated the importance of separating the businesses' day-to-day decisions from political decisions tied to community governance. The authors describe these elements as "institutional prerequisites for successful profitability when a First Nation enters an economic enterprise either independently or in joint effort with an outside firm." This point is consistent with results from the Harvard Project (Cornell and Kalt 1991, Jorgensen and Taylor 2000). Merkel (2003) claims that the interference between political authority and private enterprise can noticeably slow down decisionmaking or give rise to uncertainty on the part of business partners when a newly constituted band council brings about major policy changes. In other words, political stability influences a business' development. The experiences of 6 First Nations in Western Canada place this idea in a specific Aboriginal context by insisting on separating politics from entrepreneurial management (McBride 2001).

Beyond those contextual considerations, the conditions necessary for the success of Aboriginal forestry businesses also rest on fundamental characteristics for which we lack data. Such information would be necessary to evaluate the actions taken. Within that context, we present the portrait of forestry entrepreneurs from the Ilnu community of Mashteuiatsh, located in Quebec, Canada. This case study will also verify the hypotheses presented in the literature, such as the community orientation of Aboriginal entrepreneurship and the effects of band council intervention on private forestry companies.

\section{Methodology}

We chose to study the Ilnu community of Mashteuiatsh because it includes many forestry entrepreneurs. To be included in our survey of Mashteuiatsh Ilnu forest entrepreneurs, respondents had to 1) be part of the Ilnu community of Mashteuiatsh, 2) be forestry entrepreneurs involved in harvesting, transportation, reforestation, or any other similar activities considered relevant, and 3) be managers of a business whose shares and decision-making power are mainly $(\geq 50 \%)$ held by Aboriginal interests. Potential respondents were identified with the help of the Mashteuiatsh SDEI (Société de développement économique Ilnu).

Our primary data gathering tool was a questionnaire. We met with a total of 13 Mashteuiatsh Ilnu forest entrepreneurs (hereafter named Ilnu entrepreneurs) in spring and winter 2008. In addition, 3 more candidates were identified but were not interviewed because they failed to meet our selection criteria. Due to the limited number of respondents, we chose to provide assistance when the questionnaire was being filled out. Our role consisted of explaining ambiguities regarding questionnaire interpretation, thereby increasing the quality of the answers received. During these meetings, we worked with the Ilnu entrepreneurs to complete a questionnaire that included 92 questions, most of them close-ended. In addition to each respondent's socio-demographic profile, we sought to understand their respective entrepreneurial development, management practices, and business network.

As data gathered by questionnaire raised a number of important issues, we decided to round out the research process with interviewed Ilnu entrepreneurs, the community's economic development organization, and the main clients. These semi-structured interviews with Ilnu entrepreneurs, lasting between 60 and 90 minutes, allowed us to heighten our understanding of certain elements deemed important. These included business opportunities, obstacles to starting up a business, and the impacts of the Indian Act. Other interviews in the same format were conducted with other stakeholders to confirm and enrich information gathered from Ilnu entrepreneurs. Qualitative data analysis was carried out using N'VIVO software to codify the concepts.

\section{The Mashteuiatsh Ilnu Forest Entrepreneurs}

Ilnu entrepreneurs are generally men (12 out of 13) living with a spouse (12/13) and 2 children (median) on the territory of the Mashteuiatsh community (12/13). French is the main language written and spoken in Mashteuiatsh forestry businesses. Four entrepreneurs, however, use the Innu language at their businesses. The age of these entrepreneurs is fairly polarized -10 of them are 43 or under, while 3 are over 60. None of them are between the ages of 44 and 59. The younger group has a median age of 39.5 while the median age of the older group is 62. The median age of a Inu entrepreneur on founding a business was 38 , which concurs with the results of Riverain et al. (2006), who found a higher degree of business start up among Canadians aged 25 to 44 . In addition, Borges et al. (2005) demonstrated that the median age of Quebec entrepreneurs on deciding to start a business was 35 .

Family culture in forestry operations is a recent phenome- 
non in Mashteuiatsh since 8 of the Ilnu entrepreneurs represent the first generation of forestry workers in their family. In addition, business models in the specific sector of forestry are rare in the community. Only 1 Ilnu entrepreneur had a parent who had headed a forestry business before starting his own business. However, there is a strong presence of business models in Mashteuiatsh. In fact, 12 out of 13 Ilnu entrepreneurs knew people "who own or have owned a business." The business owners in question were mainly friends and family members. In addition, 7 Ilnu entrepreneurs indicated that their mother or father had already "been self-employed or owned a business." A number of studies have shown that the presence of business owners in an area has a positive effect on the creation of businesses by improving an individual's perception of his or her own ability to carry out such a project (Arenius and Minniti 2005, Audet et al. 2005, Minniti 2005). Work by Bherer et al. (1989) and Gauthier and Proulx (2008) have demonstrated the importance of family and friends as a source of inspiration and support for Aboriginal entrepreneurs.

Training and professional experience were other indicators. The younger group ( 44 and under) was characterized by a median of 12 years of education (the equivalent of 1 year of college in Québec), while individuals in the older group (over 60 ) had a median of 5 years of education. Arenius and Clercq (2005) have shown that people with more than a high school diploma are more likely to start a business. Of the 13 respondents, 7 stated that they could identify training that they had received and felt was useful. Four identified training in forestry, and 4 in starting and managing a business. Eight Ilnu entrepreneurs had worked in forestry before starting their own business: 2 had worked in hauling and road building activities, and 4 in reforestation-one as a biologist and another for the Montagnais Band Council forest services company, which was founded in the 1990s and closed in early 2000. Interestingly, 8 respondents reported having started another business in the past in 1 of the following sectors: construction, food services, ethnotourism, or the environment. Arenius and Clercq (2005) have demonstrated a positive link between believing in one's ability to start a business and the probability of starting a business, as have Lindsay et al. (2007) within an Aboriginal context. The high level of education and past professional experience of Ilnu entrepreneurs support that hypothesis.

One of the survey's closed questions asked Ilnu entrepreneurs to provide a number of reasons that "could motivate a member of the community to start or take over a forestry business today." The reasons provided by a majority of business owners were being one's own boss (11/13), helping the community (10/13), and taking up a challenge (9/13). The need for independence and achievement is among the defining characteristics of entrepreneurs (Collins et al. 2004). We wish to draw attention to the second motive mentioned (helping the community). Scientific literature tends to identify this characteristic as a major element in indigenous entrepreneurship (Berkes and Adhikari 2005, Hindle and Lansdowne 2005, Lindsay 2005, Peredo and Anderson 2006). The interviews with Ilnu entrepreneurs revealed the importance of the social impact of their companies, particularly in terms of job creation and support for young people. The desire to create jobs corroborates the results of Anderson and Giberson
(2004). Their sample of indigenous entrepreneurs identifies job creation as the primary benefit sought. A respondent from our survey stated the following:

"A lot of work needs to be done at the social level.

I believe that job creation [...] can help."

Two Ilnu entrepreneurs also stated that at the start of their adventure, their priorities were labour and local benefits. Today, their experience has taught them that profitability must be the top priority in a private business. Their second objective, however, is still to bring maximum benefits to the community. More concretely, 3 Ilnu entrepreneurs are currently investing in a workforce training pilot project aimed at local young people. Lastly, helping and training youth is a theme for 1 Ilnu entrepreneur. On a daily basis, the "altruism" advocated by Ilnu entrepreneurs can also be seen in their social involvement. In fact, 7 out of 13 entrepreneurs say they are involved in their communities in different ways, such as volunteering, municipal administration, or coaching for youth sports clubs.

\section{The Businesses}

The community of Mashteuiatsh is home to 12 forestry businesses (owned, one way or the other, by the 13 Ilnu entrepreneurs), all located on the reserve. According to our survey, 2004 is the median year of creation of the companies. In classifying the dozen Mashteuiatsh forestry companies by their main activity, we find that 4 of them work in reforestation (planting, clearing, precommercial thinning, and scarification), 3 work in transportation, 1 in road systems, 1 in inventory, and 1 in training. We also surveyed 2 harvesting companies with very different business models. The first harvests 78 $000 \mathrm{~m}^{3}$ of wood annually, while simultaneously carrying out forestry road works and wood transportation activities. The second company subcontracts $5000 \mathrm{~m}^{3}$ in estimated harvested volume in order to manage Ilnu entrepreneur trapping grounds. The owners of this business strive to strike a balance between the territory's different activities (logging, ethnotourism, hunting, and trapping).

Ilnu entrepreneurs state that companies holding a Timber Supply and Forest Management Agreement (TSFMA) are their biggest clients. Other Ilnu entrepreneur clients are general contractors, state corporations, and forestry cooperatives. We observe that 1) Ilnu entrepreneurs work with a median of 2 clients during the year and 2) for 9 Ilnu entrepreneurs, their forestry activities constitutes their main source of income and for 6 of them it represents their only source of income. We therefore note a certain degree of vulnerability for these businesses.

Partners play an important role in the community's forestry businesses. Eight out of 12 of these businesses are managed by more than 1 person and the other 4 are managed by only 1 Ilnu entrepreneur. The following interview excerpt summarizes this point well:

"It's certainly easier with 3 people. [...] it's easier to carry out a project, easier to convince a financial partner, easier to convince a client. Our network is broader. It's a leverage effect."

Many respondents also identified partnerships between Aboriginal and non-Aboriginal members as a success factor. For a first generation of forestry entrepreneurs like we find in Mashteuiatsh, partnerships make it possible to transfer 
knowledge and expertise. Gauthier and Proulx (2008, p.17) state that "Aboriginal entrepreneurs often use partnerships to enhance or strengthen certain aspects of their business like finance, technology, know-how, procurement, and marketing." Many other authors also mention the advantages of partnerships (NAFA-OIG 2000, Parsons and Prest 2003, Graham and Wilson 2004, Hickey and Nelson 2005).

In terms of legal status, 8 of the community's 12 forestry businesses are incorporated, 2 are general partnerships, 1 is a sole proprietorship, and the last is a cooperative. The interviews with Ilnu entrepreneurs revealed that for those with "Indian" status, incorporation provides easier access to capital. To understand this point, it should be explained that the Indian Act has major legal implications for entrepreneurs with Indian status. Section 89 (1) stipulates that property situated on a reserve is inalienable, meaning that it "is not subject to charge, pledge, mortgage, attachment, levy, seizure, distress, or execution in favour or at the instance of any person other than an Indian or a band." It is therefore difficult for entrepreneurs with Indian status to acquire the capital required to start a business, since financial institutions cannot obtain collateral to guarantee loans. Through incorporation, Aboriginal businesses are freed from the identity of their owners. These businesses can possess property (like forestry machinery) that can be used as collateral. The personal properties, like a house, of the Indian owner are still inalienable. However, an Indian can avoid the inalienability constraint by establishing his business outside the reserve territory. But none of the Ilnu entrepreneurs in our study used this strategy.

\section{Obstacles Facing Businesses}

According to Ilnu entrepreneurs, the main reasons keeping members of the Mashteuiatsh community from starting their own forestry businesses are difficulty in recruiting qualified labour (10/13) and financing difficulties (10/13). All agreed on the difficulties of obtaining qualified workers. One contractor stated that "[Ilnu entrepreneurs] haven't been able to complete a contract for years because they try to hire workers from their community [and] the labour pool is limited." One Ilnu entrepreneur stated, "A number of businesses have been created. For a while, there were only a few but now there are a lot of us. So the labour pool is spread out among businesses." The labour problem is particularly significant for reforestation businesses, which require a high number of employees. Research by Gauthier and Proulx $(2008$, p.16) reveals that it is generally "difficult to recruit qualified human resources in Aboriginal communities, particularly in forestry." Financing, which has already been discussed, is another important challenge for Ilnu entrepreneurs.

Despite these difficulties and the current economic uncertainty facing Quebec's forestry industry, Ilnu entrepreneurs are confident in the future of their businesses. Economically speaking, 2 entrepreneurs stated that their profit margin had diminished in the last 5 years, and 5 had seen an increase in profits. The remaining 5 hadn't seen any changes. Twelve of the Ilnu entrepreneurs believed they would still be in business 5 years after the interview. The intended strategies of Ilnu entrepreneurs confirmed their general optimism regarding the future. In fact, 6 spoke of developing their business, 5 of diversifying their business' activities, and none intended to scale back their operations or close shop.

\section{Services for Entrepreneurs}

In light of the meetings held and interviews carried out, we can identify the main aspects that contribute to Ilnu entrepreneur success. First, the Montagnais Band Council constitutes the community's impresario. As the local government, it has the power to influence other levels of government and economic agents. It can also operate the levers of socioeconomic development, particularly by negotiating contracts with major clients. We should point out the existence of a joint committee formed of members representing the Ilnu entrepreneurs' clients and the Montagnais Band Council. The committee's objective is to harmonize Ilnu entrepreneurs' client activities with the rights and needs of the Mashteuiatsh community. Discussions address business opportunities, planning of forestry operations, and issues specific to the territory. Participants from the band council and Ilnu entrepreneurs' clients agree that this structure has strengthened the bonds of trust as well as business relations.

Secondly, we must note the existence of Développement Piekuakami Ilnuatsh (DPI), a "limited partnership that acts as a general contractor on behalf of the community" of Mashteuiatsh (Côté 2007). This entity operates independently of the council and is tasked with managing contracts signed with major businesses and state corporations. In matters of forestry, DPI subcontracts to Mashteuiatsh businesses.

Thirdly, Ilnu entrepreneurs have access to services provided by a local economic development organization-the Mashteuiatsh SDEI. According to an SDEI representative, the organization provides financial support (e.g., a bond program: a tool developed to help entrepreneurs borrow the funds they need to start their businesses) and other services for businesses as well as assistance in drawing up business plans and obtaining funding.

Lastly, large purchasers of forestry services revealed that they granted certain advantages to Ilnu entrepreneurs, either in the form of preferred access to contracts (whether or not negotiated with the band council) or through increased technical support. The table below summarizes the services available to entrepreneurs. The solid lines between stakeholders represent direct business relations with Ilnu entrepreneurs, while dotted lines represent business relations through intermediaries. It should be noted that Fig. 1 shows the absence of

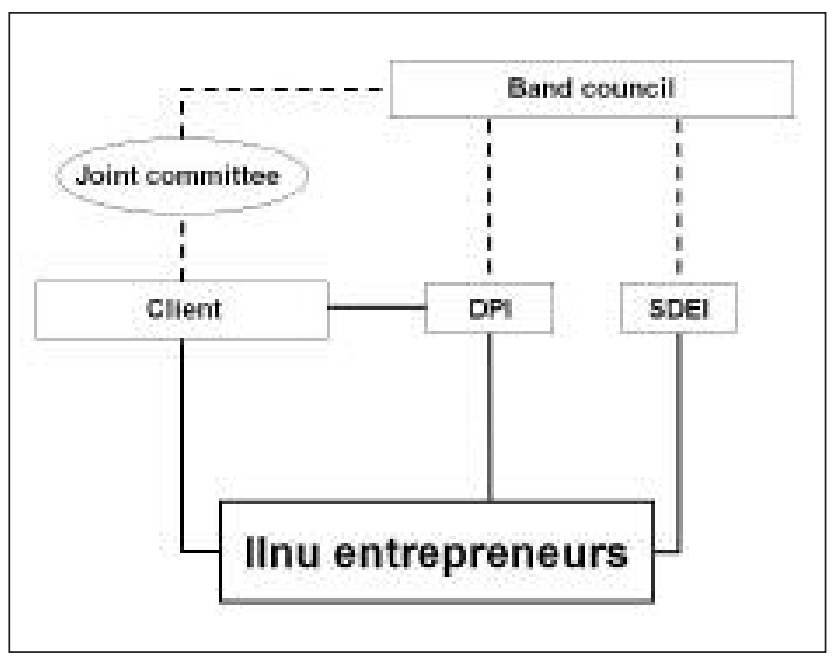

Fig 1. Services available to Ilnu entrepreneurs 
direct business relations between Ilnu entrepreneurs and the band council. The effects of that absence will be discussed in the following section.

\section{The Role of the Band Council: Supporting Without Interfering}

The interviews conducted during our study validate the hypothesis that the business-politics link can hamper a business' success (Trosper et al. 2008). As one respondent who has been involved in his community's economic development for a long time explained:

"There came a time where the council and the entrepreneurs felt that we didn't have the services we needed. When I first got involved in economic development, we were dealing mostly with band-owed businesses like the sawmill, La Plume Blanche (which was a campground), and the council's snowshoe factory. These organizations just weren't profitable. The council was often criticized for competing with private enterprise."

According to our sources, aspiring Aboriginal entrepreneurs didn't dare go into business for fear of competition from the band council, which owned a number of companies, like the sawmill, and had almost unlimited financial capacity. One respondent even spoke of a conflict of interest when referring to a time when the council owned a forestry company while it was promoting entrepreneurship in the sector. In his opinion, the council couldn't support private enterprise while competing against it without engendering mistrust. Lastly, after public consultations, the band council decided to withdraw from business development and focus instead on ways of facilitating economic development while letting local entrepreneurs do what they do best.

The need for independence between firms and politics is an element of this case study that tried to identify which factors contribute to the success or failure of Aboriginal forestry businesses. This is consistent with many scientific results (Cornell and Kalt 1991, Jorgensen and Taylor 2000, Trosper et al. 2008). It certainly contrasts with "the traditional model, where Chief and Council were responsible for the everyday management of community-owned businesses" (Graham and Wilson 2004). It also raises other questions: What should then be the role of the band council in the development of Aboriginal forestry entrepreneurship in Canada? According to Cornell and Kalt (1995), a necessary condition for economic development, observed on American Indian reservations, is the creation of formal governmental structures that "provide some mechanism of confining the government to the thirdparty enforcer role." From this, we could conclude that Band councils should focus their role on one of rules-maker, rather than being directly implicated in the board of directors of Aboriginal businesses.

At this point, we may ask what form of institution should be used by Canadian Aboriginal communities to "make the institution right"? For their part, Cornell and Kalt (1995) conclude that the creation of effective governmental institutions for economic development is a matter of cultural norms. This could explain why different US tribes are solving the problems of "getting institutions right" with approaches that differ from one tribe to another. As Trosper et al. (2008) pointed out, the Harvard Project is resourceful, but the US and Canadian contexts are not similar. For example, most of the Canadian Aboriginal communities do not own large territories.
Clearly, Aboriginal culture differences exist between US and Canada, the same way it exists among Aboriginal communities within Canada. In an attempt to resolve the institution question, it would appear to be useful to investigate the existence of an institutional difference between the communities that can provide documented experiences. In Quebec, the Mashteuiatsh and Essipit communities, which are from the same nation, could provide an opportunity for this type of study. For example, it seems that Mashteuiatsh has more private businesses while Essipit has more community-based enterprise (Gauthier and Proulx 2008). This seems an interesting opportunity for further research.

Our research has concurred with other studies that have identified joint ventures as a key business element for business success. Thus, it appears relevant to gain a better understanding of how governmental Aboriginal institutions can promote joint ventures between Aboriginal and non-Aboriginal partners.

\section{Conclusion}

Our study provides an overview of forestry entrepreneurs in the Ilnu community of Mashteuiatsh as well as their companies. According to the framework of Wyatt (2008), Mashteuiatsh participation in forestry constitutes "forestry with the First Nations," meaning forestry where the First Nations are full partners in forest management. As described in the specialized literature, we have observed the presence of key elements in Mashteuiatsh that could explain the presence of a large number of forestry businesses (Bherer et al. 1989, Arenius and Clercq 2005, Arenius and Minniti 2005, Audet et al. 2005, Minniti 2005, Gauthier and Proulx 2008). First, the band council was able to obtain access to the territory and its forest resources from the provincial government. In addition, the council created organizations to support entrepreneursSDEI and DPI. It was also able to facilitate access to capital for "Indians" in the community by creating a bond program. Lastly, through the creation of a number of partnerships, contracts, knowledge, and expertise were acquired.

The community of Mashteuiatsh is home to many young businesses that seem to be well established. Nevertheless, the challenge lies in supporting their growth on the one hand and training the next generation of entrepreneurs on the other. Our study shows that the main obstacle to forestry businesses in Mashteuiatsh is recruiting specialized Aboriginal workers. It would be interesting to evaluate whether the arrival of a first generation of Ilnu entrepreneurs in Mashteuiatsh has helped strengthen the forestry culture and attract a new generation of entrepreneurs and workers to the community. Certain studies have suggested that the presence of role models is a positive influencing factor in the perception of the desirability and feasibility of an individual adopting a certain behaviour (Bherer 1989, Arenius and Minniti 2005, Audet et al. 2005, Minniti 2005, Gauthier and Proulx 2008). In addition, certain Ilnu entrepreneurs have stated that they have recruited from other Aboriginal communities. Will Ilnu entrepreneurs have a ripple effect on communities other than their own? The question is all the more pertinent since the community includes a high proportion of young individuals (Statistics Canada 2006) and the specialized literature indicates that these young people are even more likely to adopt entrepreneurial behaviour, such as creating a business. In addition, the population of Mashteuiatsh has a high education level. We 
would have to know what the education level is in other communities, because it has been shown that education level affects business creation.

Finally, the commitment of Ilnu entrepreneurs to their communities must be mentioned. In the face of strong demographic growth and the social problems present in many of these communities, the need for employment and training is great (Proulx and Gauthier 2007). Aware that they are subject to market forces that require financial profitability, Ilnu entrepreneurs have made sure they are in a strategic position to meet this requirement. They want to help. They know and understand the reality of members of their communities. Lastly, they are already offering solutions in the form of training programs.

\section{Acknowledgements}

The authors thank all the participants to this study, particularly the Mashteuiatsh Ilnu forest entrepreneurs. We also thank the Forêt modèle du Lac-Saint-Jean, the FQRSC and the Programme de Recherche sur les Entrepreneurs de Récolte et de Transport (PREFORT/NRCAN/NSERC/ SSHRC) for the support and assistance provided.

\section{References}

Anderson, R.B. and R.J. Giberson. 2004. Aboriginal Entrepreneurship and Economic Development in Canada: Thoughts on Current Theory and Practice. International Research in the Business Disciplines 4: 141-167.

Arenius, P. and D.D. Clercq. 2005. A Network-based Approach on Opportunity Recognition. Small Business Economics 24: 249-265.

Arenius, P. and M. Minniti. 2005. Perceptual variables and nascent entrepreneurship. Small Business Economics 24: 233-247.

Audet, J., N. Riverin and M. Tremblay. 2005. L'influence de la culture d'un pays sur la propension entrepreneuriale de ses citoyens : (le cas du Canada). Université Laval, Faculté des sciences de l'administration. Report 2005-023. Québec, QC.

Berkes, F. and T. Adhikari. 2005. Development and conservation: Indigenous businesses and UNDP equator initiative. In L. Dana (ed.). Ethnic minorities in entrepreneurship. Edgard Elgar, London. Bherer, H., S. Gagnon and J. Roberge. 1989. Wampoum et lettres patentes : étude exploratoire de l'entrepreneuriat autochtone. Institut de recherches politiques, Les Presses de l'Université Laval, Québec, QC. 260 p.

Borges, C., G. Simard and L.J. Filion. 2005. Entreprendre au Québec, c'est Capital! Chaire d'entrepreneuriat Rogers-J.-A.-Bombardier, Cahier de recherche no. 2005-03.

Clercq, D. and P. Arenius. 2006. The role of knowledge in business start-up activity. International Small Business Journal 24: 339-358.

Collins, C.J., P.J. Hangesanmd E.A. Locke. 2004. The relationship of achievement motivation to entrepreneurial behavior: A metaanalysis. Human Performance 17: 95-117.

Cornell, S. and J.P. Kalt. 1991. Where's the Glue? Institutional Bases of American Indian Economic Development [online]. Available at http://www.hks.harvard.edu/hpaied/pubs/pub_012.htm [Accessed 1 June 2009].

Cornell, S. and J.P. Kalt. 1995. Successful Economic Development and Heterogeneity of Government Form on American Indian Reservations [online]. Available at http://www.hks.harvard.edu/hpaied/ pubs/pub_008.htm [Accessed 1 June 2009].

Côté, C. 2007. Développement Piekuakami Ilnuatsh. Revue Industrie \& Commerce [online]. Available at http://www.industriecommerce.com/entreprises.php?id_parution $=79 \&$ \&id_entreprise $=$ 22007\&pag [Accessed 12 December 2008].

Curran, D. and M. M'Gonigle. 1999. Aboriginal forestry: community management as opportunity and imperative. Osgoode Hall Law 37: 711-774.
Gauthier, J. and M.U. Proulx. 2008. Les conditions de l'entrepreneuriat autochtone au Québec. Colloque mi-parcours Montréal 2008. Peuples Autochtones et Gouvernance, Université de Montréal. Graham, J. and J. Wilson. 2004. First Nation and Forest Industry Relationships - Some Perspectives from British Columbia: A report for the National Aboriginal Forestry Association. The Forest Products Association of Canada, and the First Nations Forestry Program. Institute on Governance, Ottawa., ON. 52 p.

Hickey, C.G. and M. Nelson. 2005. Partnerships between First Nations and the Forest Sector: A National Survey. Sustainable Forest Management Network, Edmonton, AB. 34 p.

Hindle, K. and M. Lansdowne. 2005. Brave Spirits on New Paths: Toward a Globally Relevant Paradigm of Indigenous Entrepreneurship Research. Journal of Small Business and Entrepreneurship 18(2): 131-142.

Hutton, C. 2004. Exploring Aboriginal forestry and ecosystembased management: A case study of Cowichan tribes. School of Resource Environmental Management, Simon Fraser University, Vancouver, BC.

Jorgensen, M. and J.B. Taylor. 2000. What Determines Indian Economic Success?: Evidence from Tribal and Individual Indian Enterprises [online]. Available at http://www.hks.harvard.edu/hpaied/ pubs/pub_003.htm [Accessed 1 June 2009].

Lindsay, N.J. 2005. Toward a Cultural Model of Indigenous Entrepreneurship Attitude. Academy of Marketing Science Review 5: 1-17. Lindsay, N.J., W.A. Lindsay, A. Jordaan and K. Hindle. 2006. Opportunity recognition attitudes of nascent indigenous entrepreneurs. Int. J. Entrepreneurship and Small Business 3(1): 56-75.

Lindsay, N.J., W.A. Lindsay, A. Jordaan and G. Mapunda. 2007. Indigenous nascent entrepreneur self-efficacy and perceived individual success. Int. J. Entrepreneurship and Small Business 4(5): 605-619.

McBride, J. 2001. Our own vision - our own plan: what six First Nations organizations have accomplished with their own economic development plans [online]. Available at www.sfu.ca/cscd/Aboriginal\%20ced/Our_Own_vision8.pdf [Accessed 5 October 2008].

Merkel, G. 2003. Keeping politics out of business: Aboriginal only? Not even! Presentation made at First Nations and Sustainable Forestry: Institutional Conditions for Success, Faculty of Forestry, University of British Columbia, 24 October 2003. Vancouver, BC.

Minniti, M. 2005. Entrepreneurship and network externalities. Journal of Economic Behavior and Organization 57 (1): 1-27.

[NAFA-IOG] National Aboriginal Forestry Association and the Institute of Governance. 2000. Aboriginal-forest sector partnerships: lesson for future collaboration. Ottawa, ON.

Parsons, R. and G. Prest. 2003. Aboriginal forestry in Canada. The Forestry Chronicle 79(4): 779-784.

Peredo, A.M. and R.B. Anderson. 2006. Indigenous Entrepreneurship Research: Themes and Variations. International Research in the Business Disciplines 5: 253-273.

Proulx, M.U. and J. Gauthier. 2007. Autochtonie renaissante. In A. Lajoie (dir.). Gouvernance autochtone : aspects juridiques, économiques et sociaux. Les éditions Thémis. Montréal, QC. 246 p. Riverain N., L.J. Filion, V.Cui, Q. Du, I. Verstinsky and A. Pe'ery. 2006. Global Entrepreneurship Monitor : Le rapport canadien 2005. Chaire d'entrepreneurship Maclean Hunter, Cahier de recherche no. 2006-18.

Statistics Canada. 2006. 2006 Census: A decade of comparable data on Aboriginal Peoples.

Trosper, R., H. Nelson, G. Hoberg, P. Smith and W. Nikolakis. 2008. Institutional determinants of profitable commercial forestry enterprises among First Nations in Canada. Can. J. For. Res. 38: 226-238.

Wyatt, S. 2008. First Nations, forests lands, and Aboriginal forestry in Canada: from exclusion to comanagement and beyond. Can. J. For. Res. 38: 171-180. 